\title{
Biogenically Fabricated TMO-NPs and their Anti-Bacterial and Fungal Assay (Well Diffusion Method) in Saline Solution
}

\author{
Madiha $\mathrm{B}^{1 *}$, Shazia $\mathrm{K}^{1}$, Zahid $\mathrm{Q}^{1}$ and Ali $\mathrm{H}^{2}$ \\ ${ }^{1}$ Department of Chemistry, Government College University, LHR, Pakistan \\ ${ }^{2}$ Department of zoology Government College University LHR, Pakistan
}

*Corresponding author: Madiha Batool, Department of Chemistry, Government College University, LHR, Pakistan, Email: tweetchem56@gmail.com

\section{Research Article \\ Volume 5 Issue 1}

Received Date: December 03, 2019

Published Date: February 21, 2020

DOI: $10.23880 /$ nnoa-16000176

\section{Abstract}

Nanotechnology has attained a great deal of attention in the scientific circle. MO-NPs like copper oxide and zinc oxide, and ironoxide had been used in industry for different purposes, like paints, cosmetics and plastics. A recurrent feature that TMO-NPs exhibit is antimicrobial and fungal behavior against gram positive and negative bacteria. In this research work, we experimented the antimicrobial and antifungal activity of transition TMO-NPs nanoparticles against Gram-positive and Gramnegative bacteria. Nanosized Transition metaloxides (TMO) particles like ironoxide, copperoxide, zincoxide were biogenically synthesized by using Aloe Barbadensis leaves extract and characterized by XRD, FTIR, and TEM techniques. XRD confined the single-phase fabrication of metal oxides nanomaterials. The size of metal oxides ranges between 9-20nm. We applied these synthesized nanomaterials to assess their antibacterial and antifungal activity against E.coli, B.Subtilis, B.Licheniformis, K.Pneumonia, Aspergillus Nigar, Candida Albicanes bacteria sand fungui.: Among the MO-NPs, ZnO (zincoxide) exhibited highest antimicrobial activity against GP and GN bacterias described above in this research, while hamatite nanoparticles exhibited the lowest ZOI. Copperoxide nanoparticles demonstrated moderated results of anti-bacterial and antifungal activity.

Keywords: Nanomaterial; XRD; Antibacterial Activity; Metal Oxides; Antifungal Activity

Abbreviations: TMO: Transition Metaloxides; XRD: X-Rays Diffraction; FTIR: Fourier Transform Infrared Spectroscopy; SEM: Scanning Electron Microscopy; MBC: Minimal Bactericidal Concentration; ZOI: Zone Of Inhibition; PSA: Particle Size Analyzer; MIC: Minimum Inhibitory Concentration.

\section{Introduction}

The infectious diseases had been allured consequential threat to public health, particularly with inventions of antibiotic resistance bacterias [1,2]. The GP and GN bacterial strains create a severe health problem. Antibiotics have been referes to check the infections in community and hospital. By adventure in the nano biotechnology field
[3] nanometaloxides of desired size and shape, lead to the buildout of antibacterial agents. The functionalities of metaloxide nanoparticles are modified by the particle size [4]. In variegated fields, MO-NPs exhibit substantial functions due to their reduced sizes. The MO-NPs properties can be altered by manipulations of particle size [5]. Considering unique properties inorganic nanoparticles have being fabricated for different biomedical applications .In addition, MO-NPs nanoparticles with smaller particle size have been reported to show prominent antimicrobial and antifungal activity [6,7]. Antibactericidal and antifungal activity of nanoparticles depends on size of metal oxide nanoparticles, stability in environment, and amount in the medium growth [8]. Whereas, nanoparticles amended growing media, the bacterial growth can be inhibited by metal oxide nanoparticles 
interactions $[9,10]$. Generally, size of bacterial cell wall is in the mm range, but outer cell membranes possess pores in $\mathrm{nm}$ range [11-13]. Since nanoparticles can be smaller in size than bacterial pores, MO-NPs being in nanometer range have a ideal ability of crossing the outer cell membrane of pathogenic bacteria and fungi. A strong challenge is on spot, while synthesizing MO-NPs, to restrict growth of bacterial in nutrient medium [14]. Least information is present on the antimicrobial activities of metal oxide NPs in comparison to reports on the properties [15-17]. Furthermore, we designed to fabricate biogenically zinc oxide, iron oxide and copper oxide NPs by using Aloe Barbadensis and finally performed their antibacterial activities against GP and GN bacterial strains.

\section{Material and Method}

\section{Synthesis of Camellia Sinensis Leaves Extract}

Aloe Barbadensis plant was purchased from the botanical garden of the institute GCU Lahore. The leaves extract were prepared by washing 25-gram leaves with distilled water. The obtained leaves material was dissolved in $100 \mathrm{ml}$ of water in a $250 \mathrm{ml}$ flask and allowed to boil for $10 \mathrm{~min}$ at $80^{\circ} \mathrm{C}$ and then allowed to cool down to room temperature [18-21]. The resulting solution was filtered twice using 0.2 micrometer filter paper to remove any impure particles. The colored solution of Aloe vera leaves was now ready for further use. The calculated $\mathrm{PH}$ of that solution was $\mathrm{PH}=4$ at room temperature. The calculated $\mathrm{PH}$ of that solution was 4 at room temperature.

\section{Fabrication of Nano Metaloxides}

About 4M solution of salts of metal (iron, copper, zinc) were put into $25 \mathrm{ml}$ Aloe Vera leaves extract in a $250 \mathrm{ml}$ Erlenmeyer flask with constant shaking with a magnetic stirrer under heating at temperature $100-120^{\circ} \mathrm{C}$ range. The Color of the reaction mixture was changed. Then the resultant solution underwent centrifugation by using (Beckman JA-17 rotor model), at $10,000 \mathrm{rpm}$ for $10-15 \mathrm{~min}$, at room temperature $\left(35^{\circ} \mathrm{C}\right)$ and solid particles were collected after discarding the supernatant. The particles were washed twice with deionized water and ethanol. The collected MO- NPs were dried in a watch glass for evaporation of extra liquid. The formed black precipitate was annealed at 500 degree for $2 \mathrm{~h}$ followed by grinding for further characterization [22-24].

\section{Characterization Techniques}

The characterization techniques applied in the lab were UV spectroscopy, FTIR (Fourier transform infrared spectroscopy), XRD (X-rays diffraction), and SEM (scanning electron microscopy) [25]. In order to characterize metal oxide nanoparticles all techniques considered a tool for analysis. These techniques provide morphology, size, shape, and structure information. We can conclude the results with these techniques. The instrumental principal and data handling play a key role in precise readings. Results of characterization are listed below (Figures 1-3).

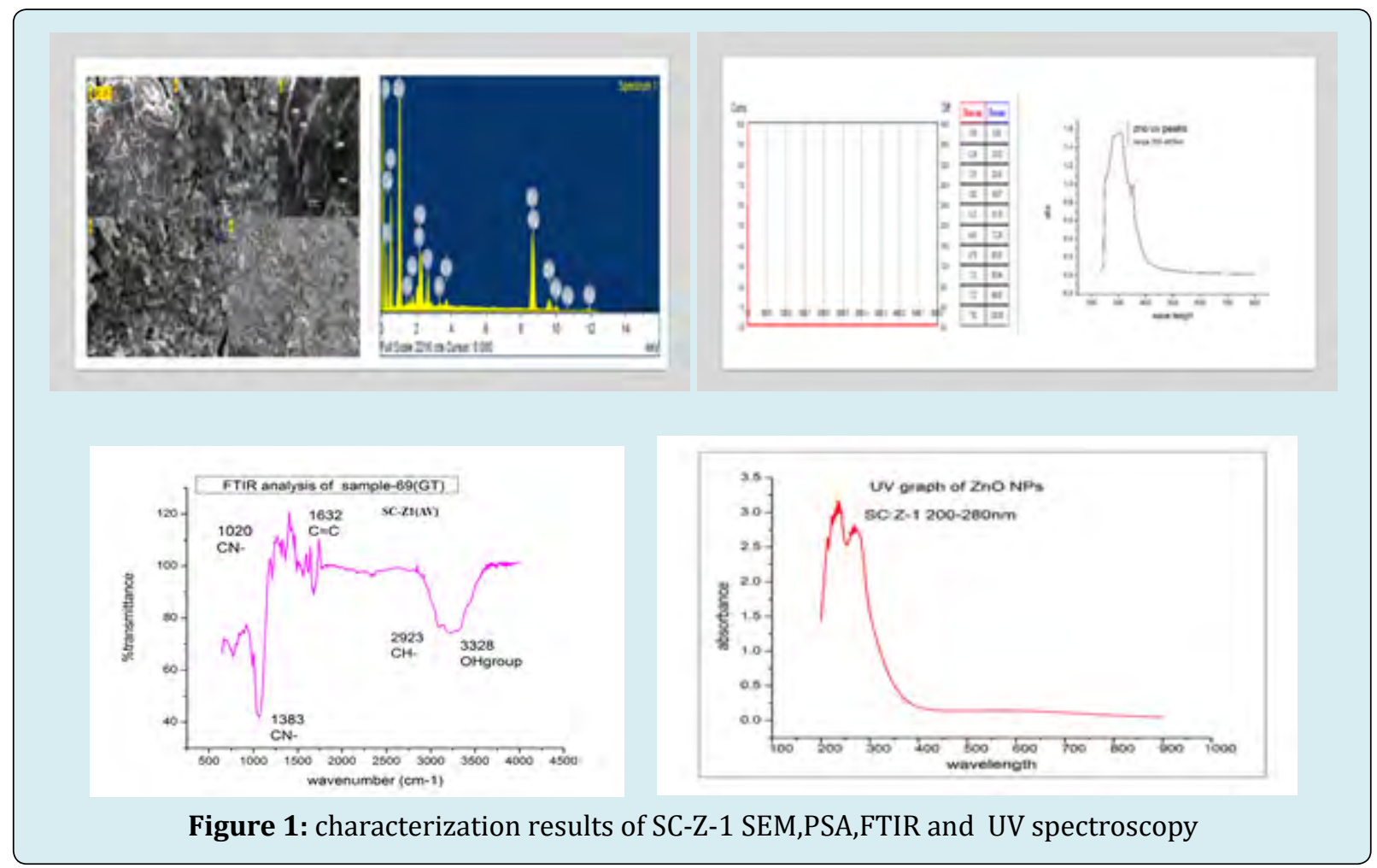

Madiha B, et al. Biogenically Fabricated TMO-NPs and their Anti-Bacterial and Fungal Assay (Well Diffusion Method) in Saline Solution. Nanomed Nanotechnol 2020, 5(1): 000176. 

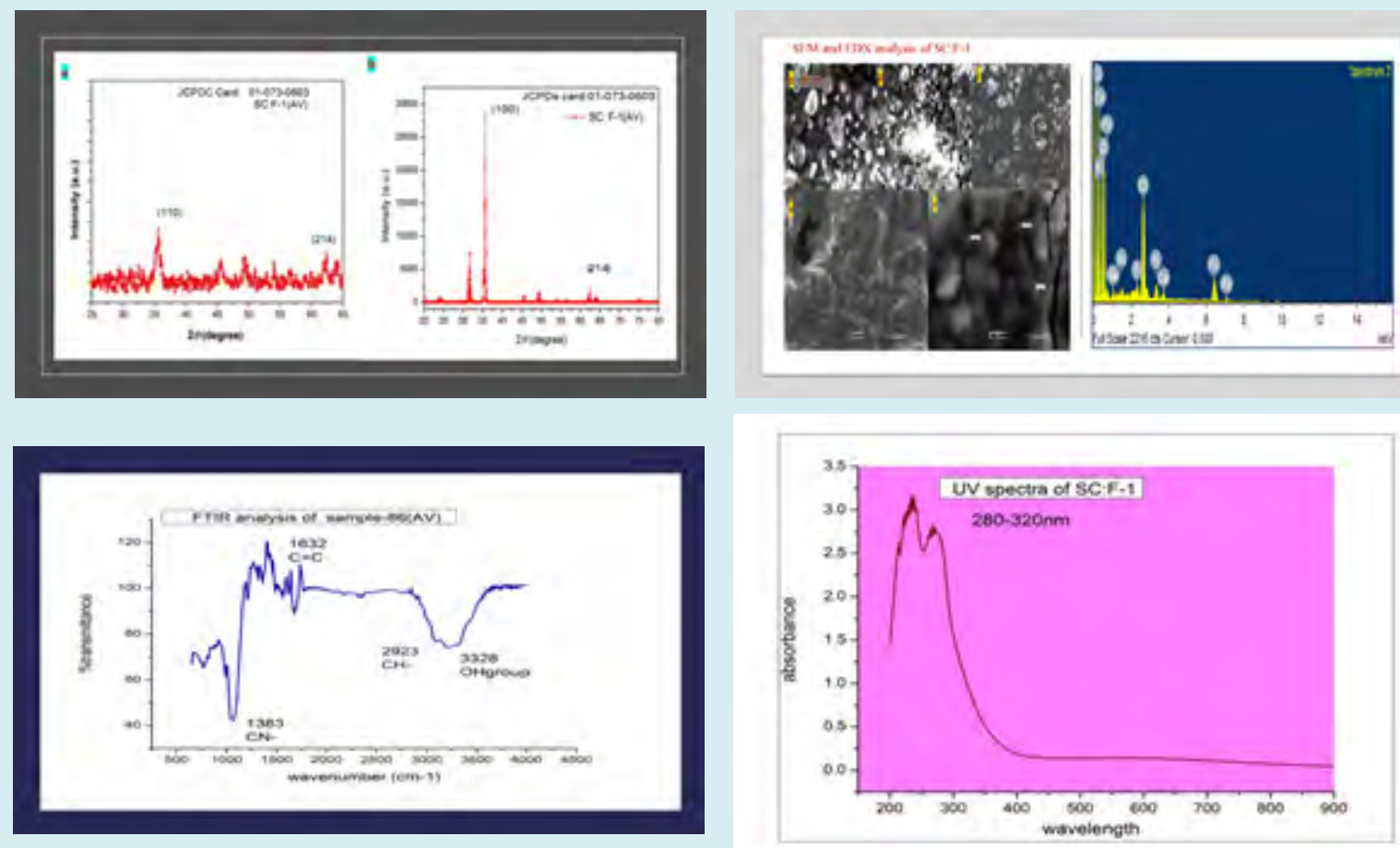

Figure 2: characterization results of SC-F-1 SEM,PSA,FTIR and UV spectroscopy.
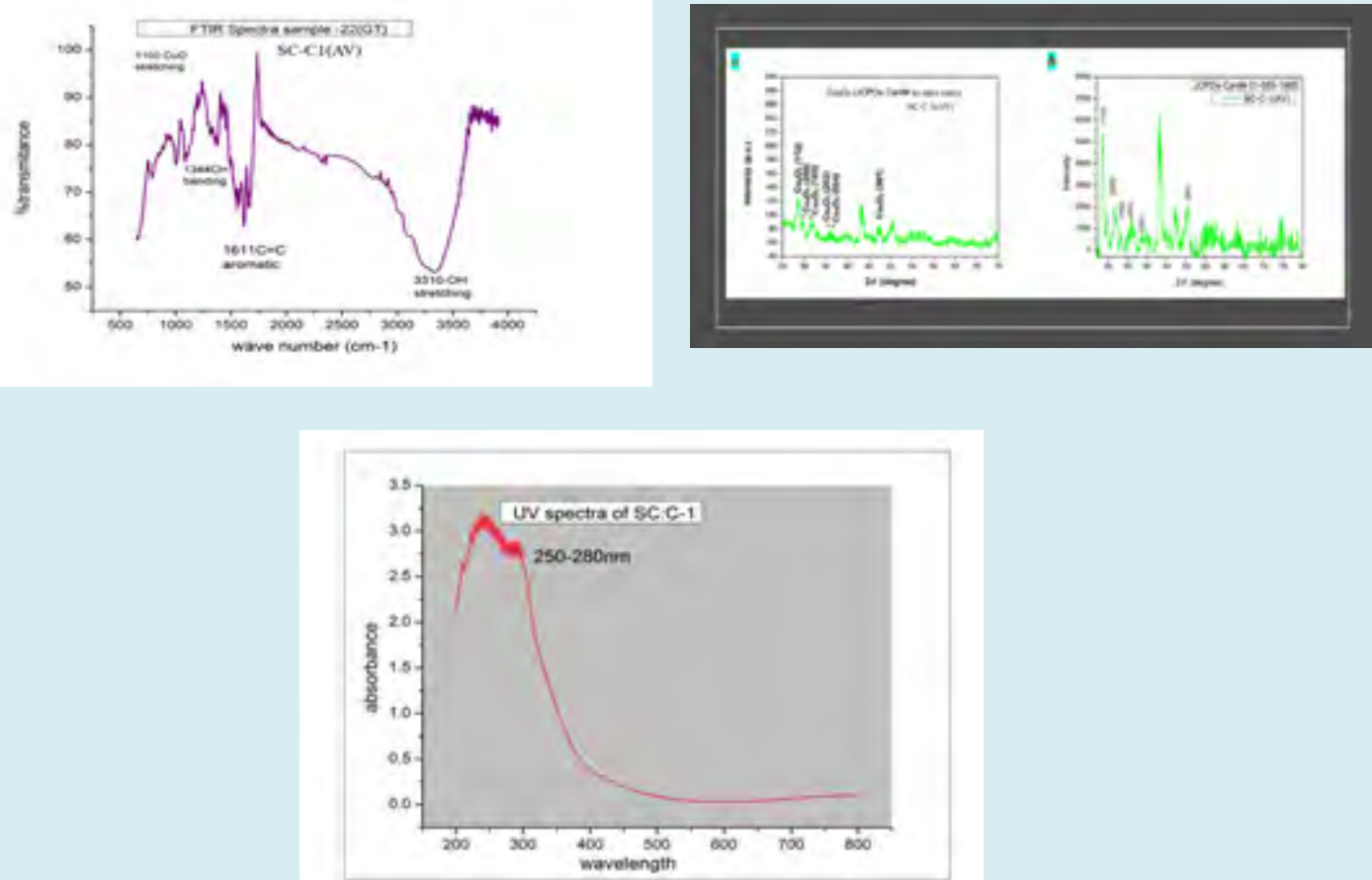

Figure 3: characterization results of SC-C-1 SEM,PSA,FTIR and UV spectroscopy. 


\section{Antibacterial and Fungal Assays}

\section{Agar Well-Diffusion Method}

In agar well diffusion assay was conducted for calculation of antibacterial and antifungal efficiency calculations of metal oxides nanoparticles. From growth microorganisms incubated on nutrient agar at $35^{\circ} \mathrm{C}$ about eighteen hour ,suspended in $0.8 \%$ saline solution and turbidity adjusted to $108(\mathrm{cfu} / \mathrm{ml})$. The suspensions were used to inoculate party plates at $d=90 \mathrm{~mm}$ with sterile cotton swab on applicator. Four wells of about $5 \mathrm{~mm}$ diameters were punched and sealed with molten agar ( $0.8 \%$ agar) as precaution to leakage of samples from the bottom. MO-NPs of $10 \mathrm{mg} / \mathrm{ml}, 5 \mathrm{mg} / \mathrm{ml}, 2.5 \mathrm{mg} / \mathrm{ml}$ samples concentrations of $100 \mathrm{microgram} / \mathrm{ml}$ were applied in well excluding control one well. The deionized water, control sample, did not affect the microorganism growth. The discs were placed on culture of bacteria and fungi, incubated in air at $35^{\circ} \mathrm{C}$ for one day. Antibacterial and fungal assay was evaluated by calculating ZOI of culture by samples applied. Experiment was conducted thrice to calculate concordant readings.

\section{Broth Dilution Assay}

BMD assay was conducted to calculate MIC (minimum inhibitory concentration) and $\mathrm{MBC}$ (minimal bactericidal concentration) of TMO-NPs against microorganisms (bacteria). The assay was performed in 96 well plates, the samples of Nano metal oxides were transferred in plates in very diluted state, plates were incubated with bacterial suspension and checked final volume was 200micro liter. After time passed of $24 \mathrm{hr}$ incubation in air, MIC was examined till lowest concentration with no minimum growth in broth. MBC was calculated for low concentration of samples killing maximum bacteria inoculum with no visible growth described in Table 1.

\begin{tabular}{|c|c|c|c|c|c|c|}
\hline \multirow{2}{*}{ strains } & \multicolumn{2}{|c|}{ SC:Z-1 } & \multicolumn{2}{c|}{ SC:C-1 } & \multicolumn{2}{c|}{ SC:F-1 } \\
\cline { 2 - 7 } & MIC & MBC & MIC & MBC & MIC & 200 \\
\hline E.C & 80 & 83 & 130 & 240 & 240 \\
\hline B.S & 97 & 96 & 156 & $\geq 400$ & np & 250 \\
\hline B.L & 100 & $\geq 100$ & 178 & 250 & 200 \\
\hline K.P & 96 & 97 & 250 & $\geq 400$ & 2490 \\
\hline
\end{tabular}

Table 1: Mean Analysis of MIC and MBC by broth dilution assay of TMO-NPs.

\section{Results}

\section{Morphological Analysis}

The typical XRD pattern of MO-NPs nanoparticles after annealed at $500^{\circ} \mathrm{C}$, peak positions of copper oxide ,zinc oxide and iron oxides exhibited the tetragonal ,hexagonal and rhombohedra structures, confirmed by the JCPDC CARD 80-0075, 80-1916, and 85-0987, respectively. By using the Scherer formula crystalline size was calculated.

$$
\mathrm{D}=09 \lambda / \beta \cos \theta(1)
$$

The calculated crystallite sizes were $7.9 \mathrm{~nm}, 16 \mathrm{~nm}$, and $20.1 \mathrm{~nm}$ respectively for $\mathrm{ZnO}, \mathrm{Cu}_{4} \mathrm{O}_{3}$, and $\mathrm{Fe}_{2} \mathrm{O}_{3}$ TMONPs .FTIR spectra by using the $\mathrm{KBr}$, exhibited vibrations in the specific region $400-500 \mathrm{~cm}^{-1}$ which can be attributed to the vibrations of $\mathrm{M}-\mathrm{O}$ which confirmed the formation of $\mathrm{ZnO}, \mathrm{Cu}_{4} \mathrm{O}_{3}$ and $\mathrm{Fe}_{2} \mathrm{O}_{3}$ metal nanoparticles. The stretching peaks of groups alcohols, polyphenols, enrolls of green extract of allovers leaves also shown in spectra which acted as stabilizing and reducing agent .UV spectroscopy revealed the MO-NPs peaks b/w 200-300nm which confirmed the presence of metal oxides nanoparticles. SEM images confirmed the morphology of $\mathrm{Cu}_{4} \mathrm{O}_{3}, \mathrm{Fe}_{2} \mathrm{O}_{3}, \mathrm{ZnO}$ TMO-NPs tetragonal, rhombohedra and hexagonal respectively. PSA (particle size analyzer) calculated the average particle size accordance to XRD data.

\section{Antimicrobial Properties}

Nanoparticles of MO-NPs reported to fungicidal and bacteriostatic agents. Results of $\mathrm{AM}$ and $\mathrm{AB}$ activity revealed that $\mathrm{ZnO}$ and $\mathrm{Cu}_{4} \mathrm{O}_{3}$ nanoparticles have excellent potential for pathogenic bacterial strains and fungi. It is examined from the XRD, SEM and TEM results that zincoxide nanoparticles had smaller in size as compared to copperoxide and ironoxides NPs, It was also concluded that the AB and AF activity of the MO-NPs elevated by increasing in S/V ratio and small sizes (Figures 4-9). 

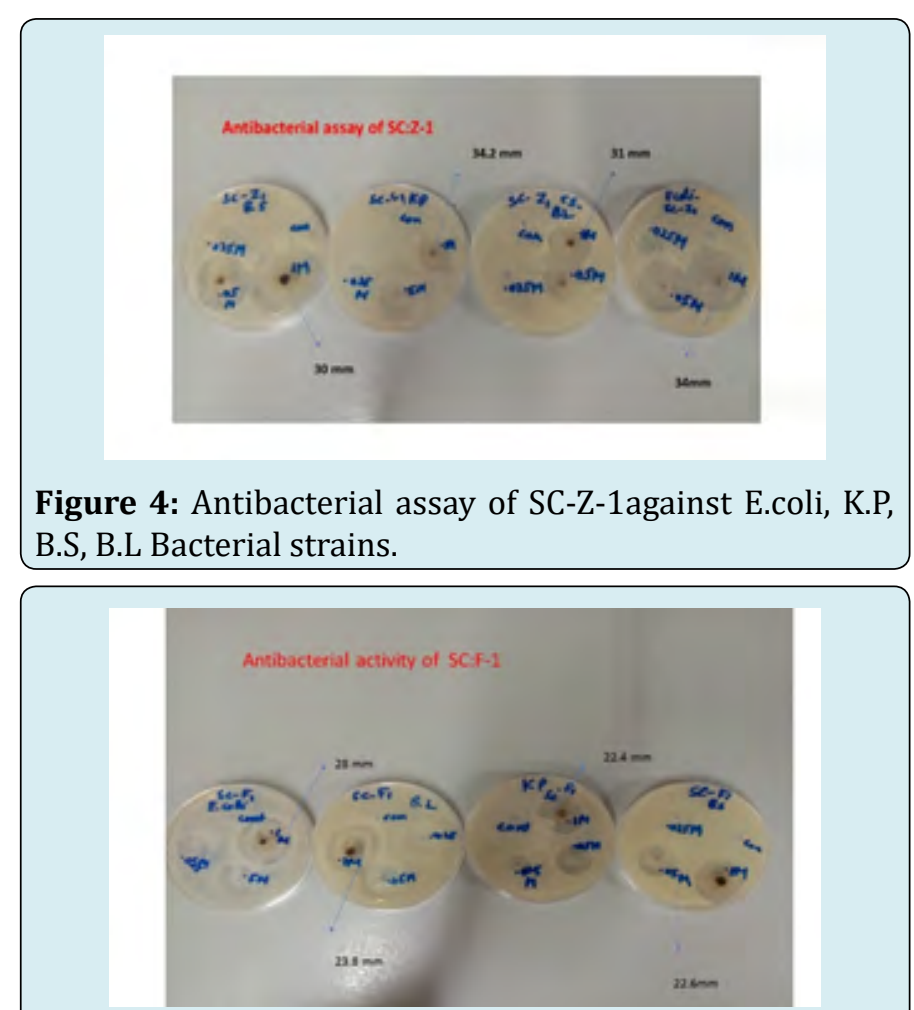

Figure 5: Antibacterial assay of SC: F- 1 against E.coli, K.P, B.S, B.L bacterial strains.

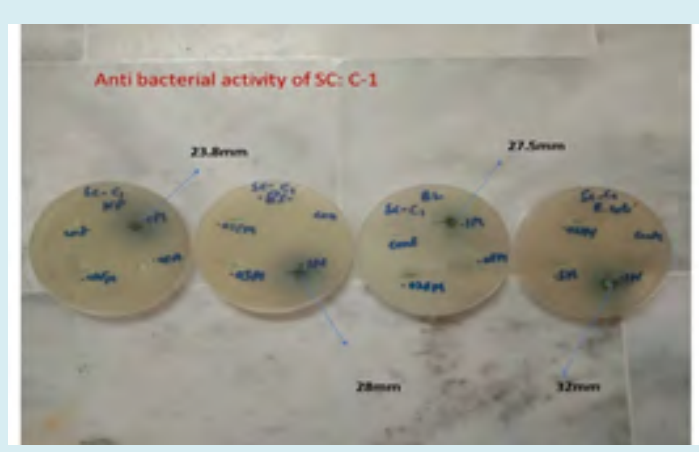

Figure 6: Antibacterial assay of SC:C-1against E.coli , K.P, B.S, B.L bacterial strains.

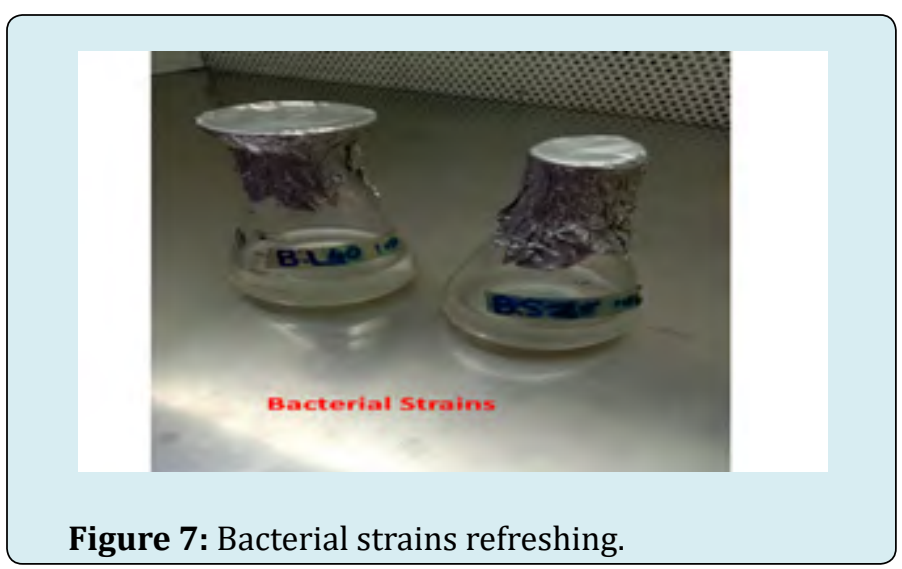

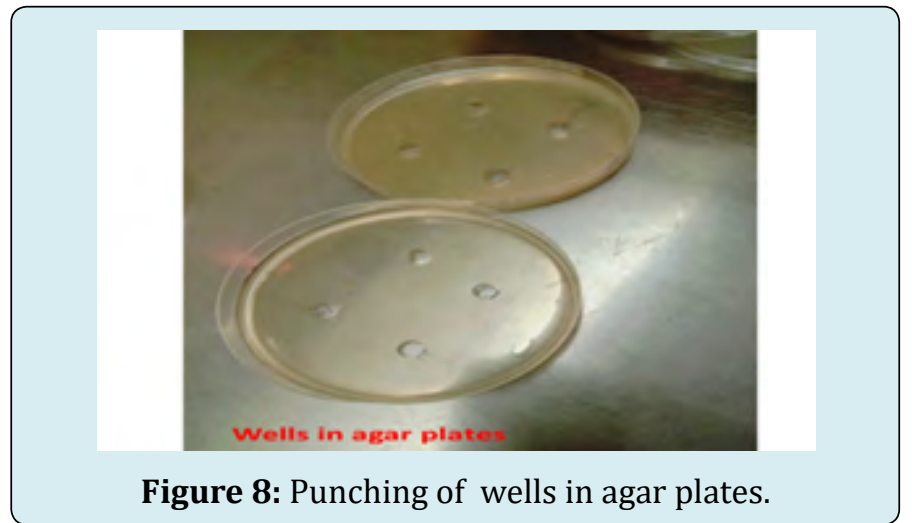

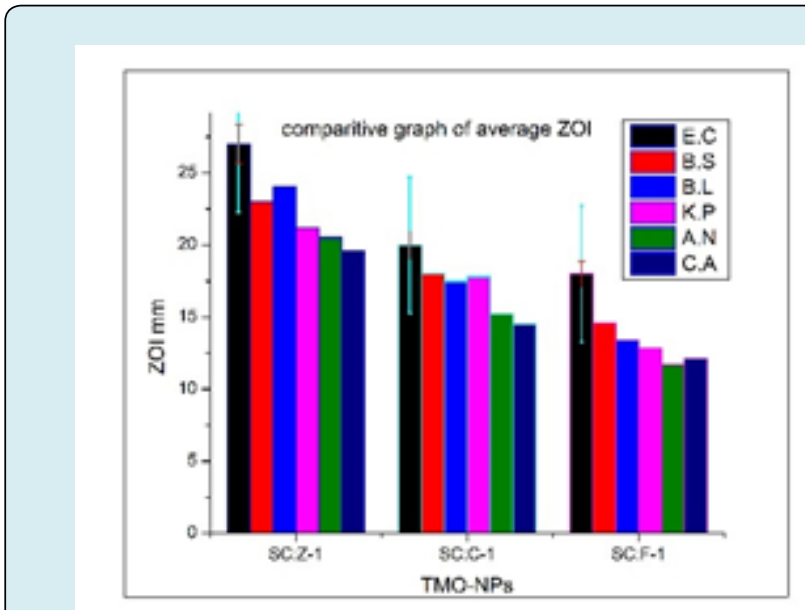

Figure 9: comparative analysis of ZOI of TMO-NPs against bacterial and fungal strains.

\section{Discussion}

The zone of inhibition (ZOI) created by transition metal oxide nanoparticles against bacterial and fungal strains by SC:Z-1 $(7.9 \pm 1.43 \mathrm{~nm})$ exhibited highest $(27 \mathrm{~mm})$ bacterial inhibition against $E$. Coli, in the form of ZOI studies, in which nanoparticles diffusion occurred on the agar nutrient plates which inhibited bacterial and fungal growth. while, SC:C1 and SC:F-1 calculated ZOI of 20 and $18 \mathrm{~mm}$ respectively against different stains. Among the bacterial strains, E.coli examined maximum ZOI others metal oxides inaugurated to be least. Similar observations were found in the case of B. substilis, B. licheniformis and K. pneumonia, where the ZOI exhibited by MO-NPs $\left(\mathrm{Fe}_{2} \mathrm{O}_{3}, \mathrm{ZnO}, \mathrm{Cu}_{4} \mathrm{O}_{3}\right)$ were summarized in the table 2 below. Zinc oxides being least particles size retained maximum ZOI against bacterial and fungal strains ,but it was also demonstrated that $\mathrm{AB}$ assay by TMO-NPs provided better results than $\mathrm{AF}$ activity .It was concluded that the $\mathrm{AB}$ and AF activity of the MO-NPs elevated by increasing in $\mathrm{S} / \mathrm{V}$ ratio and small sizes. Similarly, it was also to be noted that GN bacterial strains () had higest inhibition zone than GP bacterial strains especially in the case of zincoxides, 
copperoxide, and ironoxide nanomaterials. This could also be due to GN strains resistance .we reported in recent research that the smaller the particle size of MO-NPs, efficacy in ZOI against bacterial and fungal strains enhanced, assay efficiency depends both the production of ROS (reactive oxygen species) and the nanoparticles accumulation too. It was observed with inhibition zones studies; zinc oxide nanoparticles had least efficiency against A.Niger and Candida Albicanes fungal strains. Thus, in this report, $\mathrm{ZnO}$ nanoparticles had showed the best antifungal against two strain and four antibacterial strains .It was also assessed that the potential of antibacterial and antifungal activity is time dependent after $24 \mathrm{hr}$ the ZOI calculated found to be decreased due to bacterial growth illustrated in table below.

\begin{tabular}{|c|c|c|c|c|c|c|}
\hline \multirow{2}{*}{ MO-NP } & E.C & B.S & B.L & K.P & A.N & C.A \\
\cline { 2 - 7 } & $\mathbf{m m}$ & $\mathbf{m m}$ & $\mathbf{m m}$ & $\mathbf{m m}$ & $\mathbf{m m}$ & $\mathbf{m m}$ \\
\hline SC: $\mathbf{Z}-\mathbf{1}$ & 27 & 23 & 24 & 21.2 & 20.5 & 19.6 \\
\hline SC: $\mathbf{C - 1}$ & 20 & 18 & 17.5 & 17.8 & 15.2 & 14.5 \\
\hline SC: F-1 & 18 & 14.6 & 13.5 & 12.8 & 11.7 & 12.1 \\
\hline
\end{tabular}

Table 2: Average ZOI in mm of TM0-NPs against GP-GN bacterial and fungi strains with maximum 5mg/ml MIC OF samples.

\section{Conclusion}

The nano transition metals oxides pure $\mathrm{ZnO}() \mathrm{Cu}_{4} \mathrm{O}_{3}$ (paramaleconite), and $\mathrm{Fe}_{2} \mathrm{O}_{3}$ (hamatite) were biogenically fabricated by Aloe Barbadensis plant leaves. Furthermore, the $\mathrm{AB}$ activity of all the transition metal oxides was analyzed. Antimicrobial activity enhanced with increaseing in $\mathrm{S} / \mathrm{V}$ ratio due to the particle size reduction. Among transition metal oxides $\mathrm{ZnO}$-NPs exhibited excellent antibacterial and antifungal potential, Iron oxide (hamatite) nanoparticles had the least activity.

\section{Acknowledgment}

Thanks to Dr Atif Assistant Professor GCU LHR for providing all fungi and bacterial strains for analysis and facility of lab.

\section{Disclosure}

No conflicts of interest

\section{References}

1. Shah M, Derek F, Shashi S, Suraj T, Gérrard P (2008) Green synthesis of metallic nanoparticles via biological entities. Materials 8(11): 7278-7308.

2. Komolafe $O O$ (2003) Antibiotic resistance in bacteria-an emerging public health problem. Malawi Med J 15(2): 63-67.

3. Kulkarni N, Uday M (2014) Biosynthesis of metal nanoparticles: a review. Journal of Nanotechnology 2014: 8.

4. Azam A, Ahmed AS, Oves M, Khan MS, Memic A (2012) Size-dependent antimicrobial properties of $\mathrm{CuO}$ nanoparticles against Gram-positive and -negative bacterial strains. Int J Nanomedicine 7: 3527-3535.

5. Raghupati KR, Koodali RT, Manna AC (2011) Sizedependent bacterial growth inhibition and mechanism of antibacterial activity of zinc oxide nanoparticles. Langmuir 27(7): 4020-4028.

6. Mahapatra O, Bhagat M, Gopalakrishnan C, Arunachalam KD (2008) Ultrafine dispersed $\mathrm{CuO}$ nanoparticles and their antibacterial activity. J Exp Nanosci 3(3): 185-193.

7. Tran N, Mir A, Mallik D, Sinha A, Nayar S (2010) Bactericidal effects of iron oxide nanoparticles on Staphylococcus aureus. Int J Nanomedicine 5: 277-283.

8. Jones N, Ray B, Ranjit KT, Manna AC (2008) Antibacterial activity of $\mathrm{ZnO}$ nanoparticles suspensions on a broad spectrum of microorganisms. FEMS Microbiol Lett 279(1): 71-76.

9. Rubilar O, Mahendra R, Gonzalo T, Maria CD, Amedea BS, et al. (2013) Biogenic nanoparticles: copper, copper oxides, copper sulphides, complex copper nanostructures and their applications. Biotechnology Letters 35(9): 1365-1375.

10. Yoon KY, Byeon JH, Park JH, Hwang J (2007) Susceptibility constants of Escherichia coli and Bacillus subtilis to silver and copper nano particles. Sci Total Environ 373(2-3): 572-575.

11. Ruparelia JP, Chatterjee AK, Duttagupta SP, Mukherji S (2008) Strain specificity in antimicrobial activity of silver and copper nanoparticles. Acta Biomater 4(3): 707-716.

12. Raghunath A, Ekambaram P (2017) Metal oxide nanoparticles as antimicrobial agents: a promise for the future. International journal of antimicrobial 
agents 49(2): 137-152.

13. Heinlaan M, Ivask A, Blinova I, Dubourguier HC, Kahru A (2008) Toxicity of nanosized and bulk $\mathrm{ZnO}, \mathrm{CuO}$ and TiO2 to bacteria Vibrio fischeri and crustaceans Daphnia magna and Thamnocephalus platyurus. Chemosphere 71(7): 1308-1316.

14. Liu Y, He L, Mustapha A, Li H, Hu ZQ (2009) Antibacterial activities of zinc oxide nanoparticles against Escherichia coli 0157: H7. Journal of applied microbiology 107(4): 1193-1201.

15. He L, Liu Y, Mustapha A, Lin M (2011) Antifungal activity of zinc oxide nanoparticles against Botrytis cinerea and Penicillium expansum. Microbiological research 166(3): 207-215.

16. Bauer AW, Kirby WMM, Sherris JC, Truck M (1966) Antibiotic susceptibility testing by standardized single disk method. Am J Clin Pathol 45(4): 493-496.

17. Wikler MA (2000) Methods for Dilution Antimicrobial Susceptibility Tests for Bacteria That Grow Aerobically: Approved Standard. $5^{\text {th }}$ (Edn.), National Committee for Clinical Laboratory Standards (NCCLS), Wayne PA.

18. Ansari SA, Azam A, Naqvi AH (2011) Structural and morphological study of $\mathrm{Fe}_{2} \mathrm{O}_{3}$ nanoparticles. Asian J Res Chem 4(10): 1638-1642.

19. Makarov VV, Makarova SS, Love AJ, Sinitsyna OV, Dudnik
A0, et al. (2014) Biosynthesis of stable iron oxide nanoparticles in aqueous extracts of Hordeum vulgare and Rumex acetosa plants. Langmuir 30(20): 59825988.

20. Premanathan M, Karthikeyan K, Jeyasubramanian K, Manivannan G (2011) Selective toxicity of $\mathrm{ZnO}$ nanoparticles toward Gram-positive bacteria and cancer cells by apoptosis through lipid peroxidation. Nanomedicine 7(2): 184-192.

21. Gajjar P, Pettee B, Britt DW, Huang W, Johnson WP, et al. (2009) Antimicrobial activities of commercial nanoparticles against an environmental soil microbe, Pseudomonas putida KT2440. J Biol Eng 3: 9.

22. Azam A, Ahmed AS, Oves M, Khan MS, Habib SS, et al. (2012) Antimicrobial activity of metal oxide nanoparticles against Gram-positive and Gram-negative bacteria: a comparative study. International journal of nanomedicine 7: 6003-6009.

23. Baek Y, An YJ (2011) Microbial toxicity of metal oxide nanoparticles $\left(\mathrm{CuO}, \mathrm{NiO}, \mathrm{ZnO}\right.$, and $\mathrm{Sb}_{2} \mathrm{O}_{3}$ ) to Escherichia coli, Bacillus subtilis, and Streptococcus aureus. Sci Total Environ 409(8): 1603-1608.

24. Espitia Paula JP, Nilda de FS, Jane Sélia dos RC, Nélio José de A, Renato SC, et al. (2012) Zinc oxide nanoparticles: synthesis, antimicrobial activity and food packaging applications. Food and bioprocess technology 5(5): 1447-1464. 